\title{
TURBIDITY CURRENTS: A UNIQUE PART OF NOVA SCOTIA'S AFRICAN GEOLOGICAL HERITAGE
}

\author{
CAROLANNE BLACK \\ Department of Oceanography \\ Dalhousie University \\ Halifax, Nova Scotia B3H 4J1
}

\begin{abstract}
Four hundred million years ago, when the supercontinent Pangea was torn apart, a piece of the continental crust from material that is now part of Africa broke off on the North American side. That piece of Africa became southern Nova Scotia. The African rock was made of material deposited by ancient turbidity currents. Created by submarine landslides, turbidity currents still happen today. Whether evaluating these sedimentary rocks for oil and gas deposits or for building a city, or studying the possibility of future turbidity currents along the coast to be prepared for a tsunami, turbidity currents are studied by scientists because they have an impact on Nova Scotians.

Keywords: turbidite, turbidity current, Grand Banks earthquake, Meguma Group

'Late in 1929, many banks failed. Most of them were on Wall Street, but one was already under water, off Newfoundland.' (Nisbet and Piper 1998)
\end{abstract}

\section{The events of November 18, 1929}

As Newfoundlanders were sitting down for supper, just after $5 \mathrm{pm}$ on November 18, 1929, the ground beneath them started to shake. The earthquake on the Grand Banks of Newfoundland, only 265 kilometres from the Burin Peninsula, on the south coast of the Island of Newfoundland, measured 7.2 on the Richter scale and was felt on the Atlantic coast reaching from Newfoundland to New York (Heezen and Ewing 1952, Ruffman and Hann 2006).

The earthquake itself did little damage on land because the epicentre was about $20 \mathrm{~km}$ below 2,000 $\mathrm{m}$ of water. It did, however, shake loose the sediment above and a great underwater landslide, or slump, occurred. When the sediment shifted downward, so did all the water directly above it. The surface displacement generated a high energy 
wave that propagated outward as a tsunami that was felt on the coast of the Avalon Peninsula and in parts of Nova Scotia, but was only devastating at the closest land, the south coast of the Burin Peninsula. The bays of the south coast of the peninsula are deep and become narrow near shore, which worked together to focus the wave energy. Consequently, the waves could grow and push far up onto the land. Unknown to Newfoundlanders, catastrophe was traveling toward them at the tremendous speed of approximately $144 \mathrm{~km} / \mathrm{hr}$ (Ruffman 1996).

The rumbling subsided and the sun went down on a calm ocean and clear, windless sky. Announcing its imminent arrival, about two and a half hours after the earthquake, the tsunami caused the water to drain from harbours around the Burin Peninsula. Then three large waves hit the coast within half an hour, rising up out of the lowered seas to pummel the land. The waves were perfectly timed to arrive with the high of a spring tide, the highest of tides. Wind waves would have added to the impact of the tsunami; fortunately, there were none. Most people were able to save themselves, but that night 26 people drowned as the waves swept inland and destroyed homes and fish houses (Ruffman 1996).

At the time the tsunami was generated, the earthquake was causing a very different event at the bottom of the ocean. The epicentre of the earthquake was in a region crossed by many transatlantic submarine cables and when the ground shifted, six cables immediately broke. That was no surprise. What confused scientists was the sequence of cables that broke over more than 13 hours in increasing water depth and increasing distance from the site of the epicentre. How could the earthquake cause cable breaks so far from its origin and in a sequence (Heezen and Ewing 1952)?

On December 21 of 1929, J. W. Gregory published a letter in Nature. It was the first attempt to explain the cable breaks of 1929, as he said, a total of ' 12 cables broken in 28 places.' Gregory explained the breaks by describing faults along the submarine canyon off the Cabot Strait, now known as the Laurentian Channel. He was the first of a series of scientists to attempt an explanation, although none were correct. That is, until Heezen and Ewing came along.

Twenty-three years after the event that David Piper, a geologist and turbidite expert at the Bedford Institute of Oceanography, calls '1929', American scientists Heezen and Ewing attributed the breaks to a giant turbidity current that flowed across the ocean floor breaking cables as it passed. Later, Piper et al. (1988) found that the current reached 
speeds of up to and greater than $67 \mathrm{~km} / \mathrm{h}$, basing their estimate on the distance between the cables and the time between breaks.

As Dr. Piper said, '1929 was a big draw.' The 1929 turbidity current has been well studied and drew the interest of scientists because so much was known about it. Happening out of view and being as difficult to predict as earthquakes, turbidity currents tend to go unnoticed. But, in Piper's words: 'In terms of earthquake-triggered turbidity currents, until 1979, 1929 was I think, the only one that was particularly monitored and particularly understood. And it was monitored because all these cables got broken.' The method of monitoring is described by Heezen and Ewing (1952): 'The instants of the cable interruptions were accurately recorded by automatic machines which record the telegraphic messages, and the locations of the breaks were determined by resistance measurements from the shore ends of the cables.' The result was a unique set of data on turbidity currents.

\section{What is a 'turbidity current'?}

Turbidity currents are one type of a group of phenomena called gravity currents. A familiar example of a gravity current is a cold front moving in, often accompanied by thunderstorms. Cold air is denser and therefore heavier than warm air, so it presses horizontally under the warmer air.

A second example, more akin to a turbidity current, is an avalanche. When a mountainside of snow becomes unstable, it can start to accelerate downhill: its rumble will echo through the mountain range. The destruction can be devastating. If the avalanche is made of powder snow mixed with the air above, then it is a gravity current, and not a slide, like a mud slide. Turbidity currents are the submarine big brothers of powder avalanches, but instead of snow it is mud and sand that make up the excess density of the water they inhabit. The dense, sediment-laden water flows down the side of the continental slope to the deep sea.

To initiate a slump-induced turbidity current, a submarine landslide mixes sediment up into the water column. The particles of sediment are more dense than the water around them and have a tendency to settle out, but before this happens the muddy water may start to flow downslope. Once the current begins to flow, it quickly becomes violent. The sediment is turbulently mixed vertically through the full height of the current, maintaining it in suspension. Larger currents even dig up sediment as they go, giving themselves more driving 
energy. The largest in the world are sometimes energetic enough to gouge great canyons into the sides of continental slopes (Choux et al. 2005, Parker et al. 1986).

Upon reaching the deep ocean, turbidity currents find themselves on relatively flat ground and start to lose momentum. At this point 'the sediment will deposit and the current, having lost its raison d'être, must vanish' (Parker 1982).

And they do vanish, leaving behind great fan shapes of sediment. Nisbet and Piper (1998) found that when the 1929 current deposited sediment, it could have covered Texas in waste-deep mud and sand. In a turbidity current the sand is more dense and sinks faster. It will form the bottom layers and the mud slowly rains down on top. The current subsides and what remains is a sequence of sedimentation called a turbidite. As will become clear in the next section, turbidites can maintain recognizable form over geologic time, becoming sedimentary and sometimes becoming metamorphosed rock.

\section{Halifax was built on a current}

Turbidites are formed at the bottom of the ocean, but Southern Nova Scotians live on top of one. How did sedimentary rock from the bottom of the ocean come to be on land?

Five hundred million years ago, in place of the Atlantic was another ocean, the Rheic Ocean. Mostly due to water action, such as rivers, sediment from the Saharan Shield was displaced and swept onto the continental shelf of the Rheic Ocean. When the sediment became unstable, turbidity currents were generated that uprooted the sediment and deposited it as turbidites in the deep ocean. Four hundred million years ago the Rheic Ocean grew old and closed. The crust and mantle of the bottom of the ocean were subducted, forced downward, under the North American plate until the Rheic Ocean was no more and the equatorial supercontinent Pangea was born.

When what are now the North American plate and the African plate collided, the turbidites were in the form of sedimentary rock, created by the compression of sediment during the previous millions of years. As the Rheic Ocean closed, the more dense oceanic crust was subducted under the less dense North American plate. The turbidites, made of crustal material, were either pulled down with the oceanic crust, or forced upward, folding up onto the continent. According to Barrie Clarke, Professor in the Department of Earth Sciences at Dalhousie University, when they were on the bottom of 
the ocean, the turbidites were $11 \mathrm{~km}$ thick and the lateral extent was about the distance from Halifax to Montreal. 'But they've now been accordioned. They've been shortened.' Upon their ascension onto the continent, a new mountain range was born. As Clarke said, 'We used to have something like the Himalayas here. ... This would have been a good place for ... eco-tours 400 million years ago.' The mountains are gone now, worn down by glacial erosion.

At the time of the great mountains, Nova Scotia was far from the ocean. But supercontinents are unstable; heat from the centre of the Earth builds up underneath them. Enormous convection cells in the mantle are what cause plate tectonics. The energy trapped under Pangea caused the convection cells in the mantle to change and the result was that the North American plate was torn from the African plate. The crust began by cracking, searching for the weakest point at which to break. Most cracks became failed rifts and scarred the landscape, forming, for instance, the Bay of Fundy. The successful break happened at the edge of the continental shelf, now 200m underwater (Choyce 1996). The Atlantic Ocean was born, and so was Nova Scotia, on what Clarke calls 'a chip of Africa'.

The joining line between the African turbidites and the North American plate goes laterally from the Bay of Fundy to just south of Cape Breton Island, at Chedabucto Bay. Clarke said: 'I thought the department of tourism should set up a Bedouin tent on the north side of this fault, just as you're coming into Truro. ... Get a couple of students and a camel and welcome people to Africa. ... Whenever you tell people this story about, geologically you've come to Africa, they find it quite interesting. But,' he said, 'nobody ever took me up on it. I guess it was the renting a camel part that was hard.'

The African turbidites are called the Meguma Group and in the 1960s Dalhousie geologist Paul Schenk was studying them. Barrie Clarke was a contemporary of Dr. Schenk. Dr. Clarke explained that geologists can look at rocks and decipher the paleo-current, that is, in which direction the rocks flowed. When Schenk looked at the local turbidites he found something he wasn't anticipating. As Clarke explained the problem, 'The curious thing was that the sediments were coming from off-shore. ... The source had to be southeast. ... [Y]ou can't wash sediment out of the ocean onto the land, so there had to be another source ... this source was [Africa] and of course now it's 3000 $\mathrm{km}$ away. ... Paul made this correlation across the Atlantic ocean'. 
There is still some controversy about whether or not the Meguma Group came from Africa. Another candidate is South America. When asked, Barrie Clarke's thoughts were: 'is it Morocco? It sure looks like it.' He was with Paul Schenk on an expedition to Morocco, where he was studying granites (igneous rocks), while Schenk examined the turbidites. As he described it, the two men felt at home because the geological landscape was the same as that of Nova Scotia. Because of Schenk's remarkable insight into the link between Nova Scotia and Africa, a plaque dedicated to him is outside the Killam Library (Fig 1).

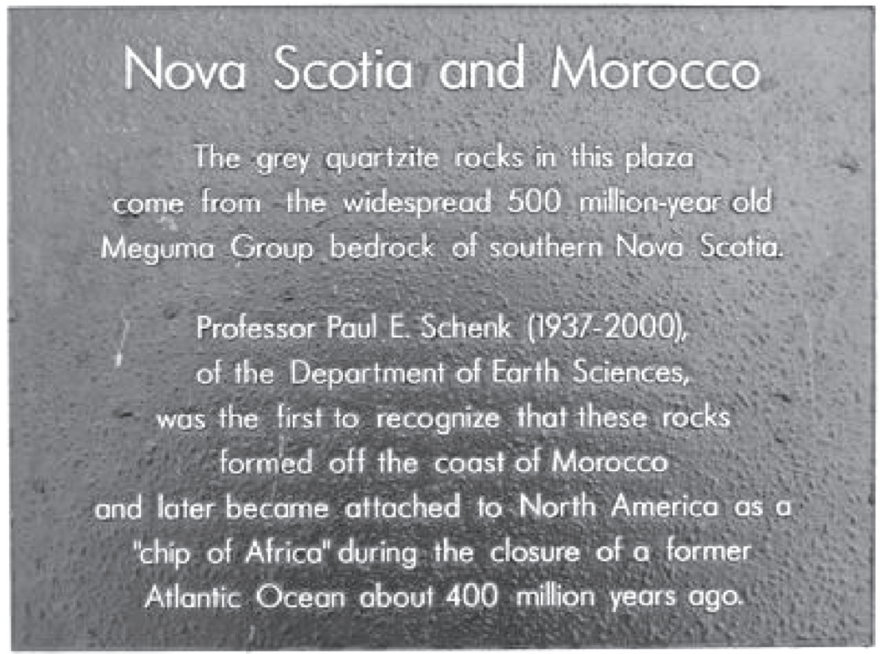

Fig 1 Plaque in honour of Geologist Paul Schenk, outside the Killam Library on the Dalhousie University campus.

\section{Nova Scotia today}

Cities are built using local rock. For Halifax, that means Meguma. For instance, at Dalhousie, the Sir James Dunn Science Building is made from the sandy, bottom layers of the Meguma turbidite, while the stone wall around campus is made of slate that was once the muddy top layers of the turbidite. At the beginning of a field trip Dr. Clarke pointed out the building and wall and explained: 'All of this stuff was quarried down in Purcell's Cove.' In front of us were the two main parts that make up the Meguma Group. 'There you have it! There's your turbidite.' 
As we drove north on the Veteran's Memorial Highway (Hwy 102) toward Kearney Lake Rd., where the entrance is found to the Gateway Material Limited quarry, Clarke gestured at the trees on our left. 'The quarry begins here. ... It's huge. Absolutely huge quarry. And you can't see it. You drive along here and you think, "oh, nice countryside." There's a great big hole over there. It's colossal! And what they're quarrying here is the turbidites.' We turned off the highway and drove a short way into the quarry, far enough to see massive piles of pulverized rock.

The next stop was Larry Uteck Drive, off the Bedford Highway. Blasting of the rock to put in the road left a vertical section of open rock face about $3 \mathrm{~m}$ high where the layers of Meguma can be seen. The coarse and heavy sands were deposited first and then the lighter muds. The sequence repeated over and over as the turbidites built up one on top of the next off the Saharan Shield (See Fig 2). Deposits from three or four consecutive turbidity currents were visible in the rock wall.

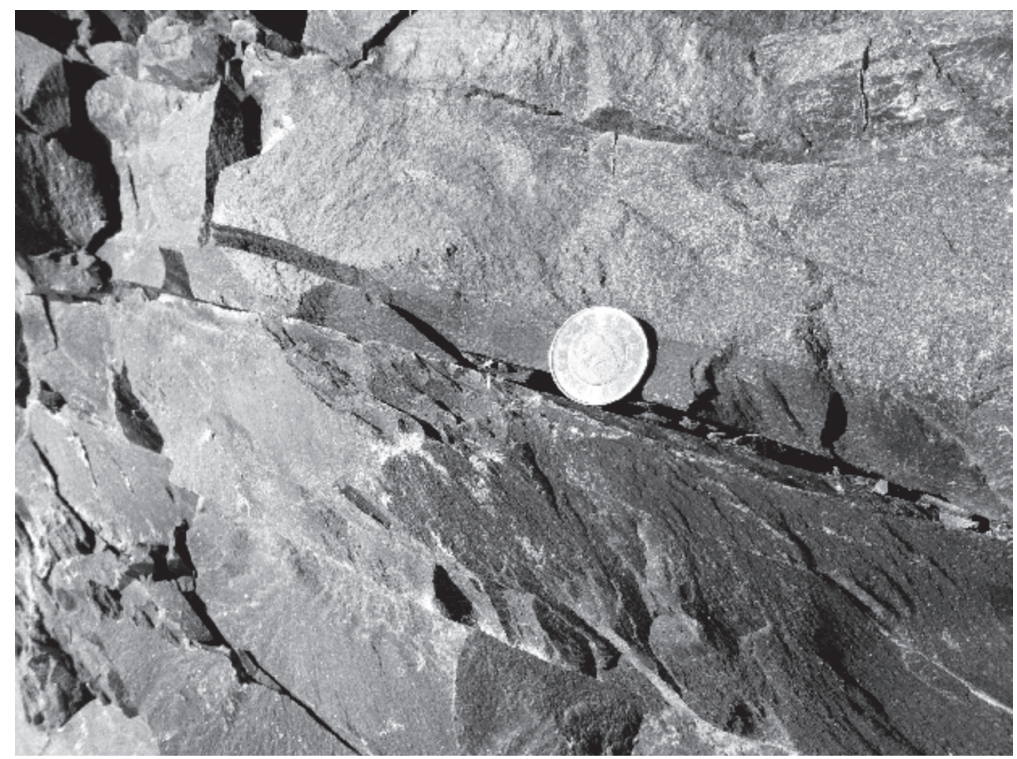

Fig 2 Exposed Meguma Group turbidite along Larry Uteck Drive. The transition from the top of one layer of turbidite to the bottom of the next is indicated by the horizontal line near the top of the toonie ( $2 \$$ coin). Darker material below is the muddy top layer. Light material above is the sandy bottom layer of the next turbidity current deposit. 
There are thin lines of differently coloured rock in the Meguma on Larry Uteck Drive that don't seem to belong. They are quartz veins, but they can contain gold. When the turbidite was compressed and folded, in places it cracked and mineral-rich water seeped in, depositing its dissolved load that eventually became quartz. Barrie Clarke commented, 'Right where this curvature is the greatest on the fold, where you're really bending these rocks, that's where they'll fracture ... and that's where you find the gold.' In Nova Scotia, all gold districts are in the form of vein deposits in the Meguma (Bates 1987).

Turbidites on the bottom of the ocean may not contain gold, but could hold a bright future in oil and gas. Grant Wach is a Professor of Petroleum Geoscience in the Department of Earth Sciences at Dalhousie University. In a recent interview Professor Wach explained the connection between turbidites and oil and gas exploration, saying that 'turbidites ... can be oil and gas bearing reservoirs.' The sandy part of a turbidite is porous and can form a reservoir for oil or gas, as long as a seal forms above it. Gas seeps up into the sandy rock and becomes trapped by the upper muddy layer, which over time has become shale. Turbidity current deposits that are 80 to 100 million years old, from the Cretaceous Period, are the right age to contain such deposits; 'that's likely when the gas was formed.' As for the Meguma Group, it lost its porosity when it was compressed as Africa collided with North America. There are, however, off-shore turbidites that show promise.

In a document entitled 'Deep Water Post-Drill Analysis: 1982-2004', wells such as the Annapolis and Crimson are described. The wells are found in the region basinward of the Sable Delta, an ancient river delta. Chevron drilled the Annapolis well in the spring and summer of 2002. Wach said, 'The objective was deep water turbidite sands and they found some gas', 'so they looked down deeper at the Crimson well.' In 2004 Marathon drilled the Crimson, about 9km from the Annapolis well, and was unsuccessful in finding hydrocarbons. When asked whether gas has been found in off-shore turbidites, Grant Wach's response was: 'Not yet. But, the potential is still there and companies are on the lookout (CNSOPB 2011).

As discussed above, turbidites are of interest to Nova Scotians, but turbidity currents are also important. Nova Scotia exists in a region of some seismic activity. To understand the local risks of catastrophic natural events, as Wach told me, scientists 'plot out earthquakes and seismicity and they try to see the periodicity of that seismicity.' When will another event like that of 1929 happen again? According to David 
Piper, in an email: 'We have evidence that a failure the size of 1929 takes place only every 100000 years in that area.' It doesn't sound like much to worry about, but, he says, tsunamis that could hit Nova Scotia, caused by submarine landslides in locations such as the Scotian Shelf, occur on the order of every 10,000 years.

Grant Wach suggested that this essay be subtitled: 'Can you tread water?', adding 'we're at risk here.' Mosher (2009) examined the possibility of landslides and tsunamis along the Canadian coastline, concluding that on the east coast, large volumes of sediment have accumulated on the Scotian Shelf and they have the potential to fail, starting a submarine landslide. If this were to happen, a tsunami would be generated that could reach the coast of Nova Scotia within a few short hours, leaving little time for local people to react. In the meantime, Nova Scotians go about their lives on 'a chip of Africa'.

Acknowledgements Nova Scotians amaze me with their kindness and their willingness to give of themselves. Eric Mills helped generate ideas and focus the project. He also edited the essay. David Piper is the acknowledged expert in turbidity flows and made the time for a long interview during which he explained the history of the study of turbidity currents. Grant Wach helped me understand the connection between turbidites and hydrocarbon exploration. Alan Ruffman, via email, answered in detail, questions about tsunamis. Barrie Clarke took me on a field trip, answered my never-ending questions and succeeded in transmitting his enthusiasm for geology to me.

\section{REFERENCES}

Bates, J.L.E. (1987). Gold in Nova Scotia, Tech. rep., Nova Scotia Department of Mines and Energy.

Choux, C., Baas, J., McCaffrey, W., Haughton, P. (2005). Comparison of spatio-temporal evolution of experimental particulate gravity flows at two different initial concentrations, based on velocity, grain size and density data, Sedimentary Geology 179: 49-69.

Choyce, L. (1996). Nova Scotia: shaped by the sea, Penguin Group.

Clarke, D.B. (2011). (Department of Earth Sciences, Dalhousie University) Personal communication.

CNSOPB. (Canada-Nova Scotia Offshore Petroleum Board). (2011). Lands Management: Call for bids.

Heezen, B.C., Ewing, M. (1952). Turbidity currents and submarine slumps, and the 1929 grand banks earthquake, American Journal of Science, 250: 849-873. 
Mosher, D.C. (2009). International year of planet earth 7. oceans: Submarine landslides and consequent tsunamis in Canada, Geoscience Canada, 36: $179-189$.

Nisbet, E., Piper, D. (1998). Giant submarine landslides, Nature, 392: 329-330.

Parker, G. (1982). Conditions for the ignition of catastrophically erosive turbidity currents, Marine Geology, 46: 307-327.

Parker, G., Fukushima, Y., Pantin, H. (1986). Self-accelerating turbidity currents, Journal of Fluid Mechanics, 171: 145-181.

Piper, D.J.W. (2011) (Bedford Institute of Oceanography, Halifax) Personal communication.

Ruffman, A. (1996). Tsunami runup mapping as an emergency preparedness planning tool: the 1929 tsunami in St.Lawrence, Newfoundland,Tech. rep., Office of the Senior Scientific Advisor Energy Preparedness Canada.

Ruffman, A. (2011). (Department of Earth Sciences, Dalhousie University) Personal communication.

Ruffman, A., Hann, V. (2006). The Newfoundland tsunami of November 18, 1929: An examination of the twenty-eight deaths of the "south coast disaster", Newfoundland and Labrador Studies, 21: 1719-1726.

Wach, G.D. (2011). (Department of Earth Sciences, Dalhousie University) Personal communication. 